\title{
Regulation of 5- $\mathrm{HT}_{2 \mathrm{~A} / \mathrm{C}}$ Receptors and DOI-Induced Behaviors by Protein Kinase C y
}

\author{
Barbara J Bowers ${ }^{a},{ }^{*}$, Jill Miyamoto-Ditmona ${ }^{a}$, and Jeanne M Wehnera,b \\ a Institute for Behavioral Genetics, University of Colorado, Boulder, CO 80309 \\ b Department of Psychology, University of Colorado, Boulder, CO 80309
}

\begin{abstract}
Protein kinase $\mathrm{C} \gamma(\mathrm{PKC} \gamma)$ null mutant mice demonstrate increased behavioral impulsivity and ethanol consumption. Pharmacological studies have shown that $5-\mathrm{HT}_{2 \mathrm{~A} / \mathrm{C}}$ receptors modulate impulsivity and ethanol consumption in rodents and that $\mathrm{PKC}$ can regulate $5-\mathrm{HT}_{2 \mathrm{~A} / \mathrm{C}}$ receptors. To determine whether $\mathrm{PKC} \gamma$ plays a selective role in $5-\mathrm{HT}_{2 \mathrm{~A} / \mathrm{C}}$ receptor regulation, biochemical and behavioral experiments were performed in PKC $\gamma$ mutant and wild-type mice. DOI-stimulated phosphoinositol hydrolysis and $\left[{ }^{125} \mathrm{I}\right]-\mathrm{DOI}$ saturation binding in the PFC, and quantitative autoradiography of $\left[{ }^{125} \mathrm{I}\right]$-DOI binding sites in 15 brain regions were analyzed. DOI-induced head twitch responses (HTR) were measured in naïve mice after an acute $2.5 \mathrm{mg} / \mathrm{kg}$ injection of DOI. Results indicated that DOI-induced HTR was significantly greater in mutant mice compared to wildtype mice. Results of the phosphoinositol hydrolysis, membrane binding, and autoradiography experiments indicated that in mutant mice, increased HTR was associated with increased 5$\mathrm{HT}_{2 \mathrm{~A} / \mathrm{C}}$ receptor function in the $\mathrm{PFC}$, but not increased receptor number or affinity suggesting that $\mathrm{PKC} \gamma$ regulates receptor function but not receptor number. These data support a role for 5- $\mathrm{HT}_{2 \mathrm{~A} / \mathrm{C}}$ receptors in the PFC in mediating some of the behavioral differences observed between PKC $\gamma$ mutant and wild-type mice.
\end{abstract}

\section{Keywords}

PKC $\gamma$; mice; phosphoinositol hydrolysis; quantitative autoradiography; head twitch response; DOI; $5-\mathrm{HT}_{2 \mathrm{~A} / \mathrm{C}}$ receptors

\section{INTRODUCTION}

Null mutant mice lacking the neuronal-specific gamma isotype of protein kinase $\mathrm{C}(\mathrm{PKC} \gamma)$ are more impulsive in an appetitive signaled-nosepoke task and consume more ethanol in a freechoice paradigm when compared to wild-type control mice (Bowers and Wehner, 2001). The neural mechanism by which PKC $\gamma$ impacts these behaviors is most likely complex. However, $\mathrm{PKC} \gamma$ is primarily located post-synaptically; therefore, it is possible to limit the investigation of mechanisms to post-synaptic processes. A logical neurotransmitter candidate is the serotonin (5-HT) system, as numerous human and animal studies have shown that dysfunction of the central serotonergic system is related to both increased behavioral disinhibition (Harrison et

*Corresponding author: Barbara J Bowers, PhD, Institute for Behavioral Genetics, UCB 447, University of Colorado, Boulder, CO 80309 , Ph: (303) 735-0077, Fax: (303) 492-8063, e-mail: bbowers@colorado.edu.

Publisher's Disclaimer: This is a PDF file of an unedited manuscript that has been accepted for publication. As a service to our customers we are providing this early version of the manuscript. The manuscript will undergo copyediting, typesetting, and review of the resulting proof before it is published in its final citable form. Please note that during the production process errors may be discovered which could affect the content, and all legal disclaimers that apply to the journal pertain. 
al., 1997; 1999; Ho et al., 1998; Leyton et al., 2001) and increased ethanol consumption (FilsAimee et al., 1996; LeMarquand et al., 1994a, 1994b; McBride et al., 1995; Murphy et al., 1982).

The 5-HT receptor system is heterogeneous with at least 15 subpopulations of neuronal receptors from 7 distinct families $\left(5-\mathrm{HT}_{1}-5-\mathrm{HT}_{7}\right)$, which are encoded by different genes (Barnes and Sharpe, 1999). One of these families, $5-\mathrm{HT}_{2 \mathrm{~A} / \mathrm{B} / \mathrm{C}}$, has been shown to be associated with PKC such that agonist-stimulated receptor desensitization and down-regulation are regulated by PKC activity (Anji et al., 2001; Kagaya et al., 1990; Roth et al., 1998). A recent investigation of $\mathrm{PKC}$ isotype expression in neonatal rat spinal cord after $5-\mathrm{HT}_{2}$ receptor stimulation reported that gene expression for the $\mathrm{PKC} \gamma$ isotype was upregulated after treatment with the 5- $\mathrm{HT}_{2 \mathrm{~A} / \mathrm{C}}$ agonist, 2-5-dimethoxy-4-iodoamphetamine (DOI) (MacDonald et al., 2001). In addition, Anji et al. (2001) implicate PKC $\alpha$ and $\mathrm{PKC} \gamma$ in the regulation of 5-HT2A receptor mRNA. This suggests a possible selective role of $\mathrm{PKC} \gamma$ in $5-\mathrm{HT}_{2}$ receptor regulation. Further support for this association is indicated by the shared brain regional localization of $\mathrm{PKC} \gamma$ and 5- $\mathrm{HT}_{2}$ receptors, including prefrontal cortex, as well as their post-synaptic localizations (Backstrom et al., 2001; Naik et al., 2000; Pazos et al., 1985; Thomas and Everitt, 2001).

In the present study, experiments were designed to explore further the potential link between $\mathrm{PKC} \gamma, 5 \mathrm{HT}_{2 \mathrm{~A} / \mathrm{C}}$ receptors, prefrontal cortex (PFC), and altered behavioral responses in $\mathrm{PKC} \gamma$ mutants compared to wild-type mice. To test the hypothesis that PKC $\gamma$ null mutant mice have a dysregulation in the function and/or number of 5- $\mathrm{HT}_{2 \mathrm{~A} / \mathrm{C}}$ receptors in the $\mathrm{PFC}$, we evaluated DOI-stimulated phosphoinositol (PI) hydrolysis in slices isolated from the PFC of mutant and wild-type mice. In addition, we measured [ $\left.{ }^{125} \mathrm{I}\right]$-DOI binding using tissue extracts from the PFC followed by quantitative autoradiography of [ $\left.{ }^{125} \mathrm{I}\right]$-DOI binding sites in several brain regions including the $\mathrm{PFC}$ and other regions associated with drug reward. To confirm the role of $5-\mathrm{HT}_{2 \mathrm{~A} / \mathrm{C}}$ receptors in regulating behavioral differences between $\mathrm{PKC} \gamma$ mutant and wild-type mice, we extended our previous studies of behavior to include a characterization of DOI-induced head twitch responses (HTR) because this response is regulated by the serotonin system in the PFC (Willins and Meltzer, 1997). The head twitch response is a behavioral manifestation of the functional activation of 5- $\mathrm{HT}_{2}$ receptors (Darmani and Gerdes, 1995; Darmani et al., 1990; Darmani et al., 1992; Willins and Meltzer, 1997) and can be measured easily and quickly in mice.

\section{MATERIALS AND METHODS}

\subsection{Animals}

Male and female mice were 80-120 days of age at the time of testing and were housed in likesex groups of 2-5. Mice were given food and water ad libitum and maintained on a $12 \mathrm{hr} \mathrm{light/}$ dark cycle (lights on at 7:00 AM). PKC $\gamma$ null mutant mice were derived using gene-targeting and homologous recombination techniques (Abeliovich et al., 1993) and are currently bred on an F1 C57BL/6 X 129/S6 mixed genetic background at the Institute for Behavioral Genetics (Boulder, $\mathrm{CO}$ ). The $\mathrm{F} 1$ generations are bred from heterozygous crosses from two congenic strains: C57BL/6.PKC $\gamma$ and 129/S6.PKC $\gamma$. This breeding strategy produces homozygous mutant, heterozygous, and homozygous wild-type genotypes within a single litter, thereby providing wild-type littermate controls for each experiment. The PKC $\gamma$ mutation is maintained in a heterozygous condition on C57BL/6 and 129/S6 inbred strains because homozygous null mutant mice do not survive on the C57BL/6 background (Bowers et al., 1999). All mice were genotyped prior to testing using DNA analysis of tail DNA as described previously (Bowers and Wehner, 2001). Groups of null mutant and wild-type littermate control mice used in the following experiments were derived from multiple litters. All animal use procedures were 
performed in accordance with the NIH Guide for Care and Use of Laboratory Animals and were approved by the University of Colorado IACUC.

\subsection{Phosphoinositol (PI) Hydrolysis}

Male and female PKC $\gamma$ mutant $(n=8)$ and wild-type mice $(n=8)$ were sacrificed by cervical dislocation; the brains were rapidly removed and placed in an ice-cold brain matrix where the prefrontal cortex (PFC) was removed for slicing. Tissue from PFC was sliced ( $400 \mathrm{nM}$ thick) with a McIlwain tissue chopper. Assay conditions were based on a protocol described by Berridge et al. (1982) with the following modifications. Slices were labeled for $60 \mathrm{~min}$ with $\left[{ }^{3} \mathrm{H}\right]$-myoinositol (3uCi/tube) (Perkin Elmer, $18.5-25 \mathrm{Ci} / \mathrm{mmo}$ ) in the presence of $\mathrm{LiCl}(10 \mathrm{mM})$ and pargyline $(10 \mathrm{uM})$. Agonist stimulation was done by incubation for 60 min with DOI (10 uM final). This concentration was based on results from Toscano et al. (1999) who reported maximal stimulation by DOI at $10 \mathrm{uM}$. Inositol phosphates were bound using a resin slurry (1:1, AG 1-X8 resin, formate form/ $\mathrm{H}_{2} \mathrm{O}$; Bio Rad Laboratories, Hercules, CA) added to each sample tube. Tubes were vortexed for $4 \mathrm{~min}$, then centrifuged for $5 \mathrm{~min}$ at $2600 \mathrm{rpm}$. Samples were washed $4 \mathrm{X}$ with cold $5 \mathrm{mM}$ myoinositol to remove free $\left[{ }^{3} \mathrm{H}\right]$-myoinositol. Inositol monophosphates were eluted with a final wash using $1 \mathrm{M}$ formate $/ 0.1 \mathrm{M}$ formic acid. After centrifugation aliquots of the supernatant were placed in vials containing scintillation fluid. Radioactivity was counted and agonist stimulation was calculated as a percent of basal stimulation. Proteins were measured using the method of Bradford (1976).

\section{$2.3\left[{ }^{125} \mathrm{I}\right]-\mathrm{DOI}$ Membrane Binding}

Binding experiments were done according to McKenna et al. (1989b) with some modifications. Prefrontal cortices were isolated from naive mutant $(n=3)$ or wild-type $(n=3)$ mice. The tissue was immediately homogenized in $50 \mathrm{mM}$ Tris buffer ( $\mathrm{pH}$ 7.4) containing $0.1 \%$ ascorbate and $4 \mathrm{mM} \mathrm{CaCl}_{2}$, then centrifuged. Proteins were determined by the method of Bradford (1976). Incubations were conducted in 96-well microtiter plates consisted of 20 ug protein and $0.02-$ $5.0 \mathrm{nM}$ of [ $\left.{ }^{125} \mathrm{I}\right]-\mathrm{DOI}$ (3 replicates/concentration). Non-specific binding was defined at each concentration with $1 \mathrm{uM}$ ketanserin. Reactions were terminated by filtration through glass fiber filters ( $0.38 \mathrm{~mm}$ thickness, Inotech Biosystems International, Inc., Rockville, MD) presoaked in $0.1 \%$ polyethylenimine using an Inotech Cell harvester. Filters were washed $3 \mathrm{X}$ with icecold $50 \mathrm{mM}$ Tris and were counted in a gamma counter.

\section{$2.4\left[{ }^{125}\right]$-DOI Quantitative Autoradiography}

Mutant ( $\mathrm{n}=6)$ and wild-type $(\mathrm{n}=6)$ mice were sacrificed by cervical dislocation and the brains were quickly removed and frozen in isopentane on dry ice. Brains were stored at $-70^{\circ} \mathrm{C}$ until sliced. Tissue sections ( $14 \mathrm{uM}$ thick) were cut in a cryostat at $-20^{\circ} \mathrm{C}$ and were thaw mounted onto Fisher Superfrost slides (Fisher Scientific, Pittsburgh, PA). Coronal sections were taken from 3.20, 1.70, and $1.10 \mathrm{~mm}$ anterior to Bregma to examine prefrontal cortex, rostral and caudal striatum, respectively (Franklin and Paxinos, 1997). A comparison of rostral and caudal striatum was included based on the findings of Bowers et al. (2000) that DOI stimulates DA release in caudal, but not rostral, nucleus accumbens core and shell regions. Binding was done according to McKenna et al. (1989a) with some modifications. Slides were preincubated for $20 \mathrm{~min}$ at RT in $50 \mathrm{mM}$ Tris buffer (pH 7.4) containing $0.1 \%$ ascorbate, $0.1 \% \mathrm{BSA}$, and $4 \mathrm{mM}$ $\mathrm{CaCl}_{2}$ followed by incubation for $90 \mathrm{~min}$ in the presence of $500 \mathrm{pM}\left[{ }^{125} \mathrm{I}\right]$-DOI. This concentration was chosen based on the membrane binding experiments where the signal to noise ratio was the strongest. Because the affinity of DOI for 5- $\mathrm{HT}_{2 \mathrm{C}}$ receptors is only about 10-fold greater than the affinity for the 2A site (Appel et al., 1990; Knight et al., 2004; McKenna et al., 1989a), we make the assumption that both $2 \mathrm{~A}$ and $2 \mathrm{C}$ receptor density was being measured. Non-specific binding was defined in the presence of $10 \mathrm{uM}$ ketanserin. Slides were placed in x-ray cassettes opposite Super Resolution phosphor screens (Packard Bioscience, 
Meriden, CT) for $7 \mathrm{hrs}$. $\left.{ }^{125} \mathrm{I}\right]$-standards were included in each exposure (GE Healthcare) Autoradiographic images were quantified using the Cyclone Storage Phosphor System (Packard Bioscience). Net binding density values (DLU/ $\mathrm{mm}^{2}$; total binding minus nonspecific binding) obtained for a given brain region across six consecutive tissue sections were averaged for each mouse.

\subsection{Behavioral Procedures}

On experimental days, mice were placed in a quiet testing room for one hour before injections. Testing began by placing the mouse in a clear Plexiglas box $(20 \times 26 \times 15 \mathrm{~cm})$ layered with bedding for a $20 \mathrm{~min}$ habituation period. At $20 \mathrm{~min}$, mice were injected with either saline ( $\mathrm{n}=$ 6/group) or $2.5 \mathrm{mg} / \mathrm{kg}$ DOI (Sigma-Aldrich, St. Louis, MO) ( $\mathrm{n}=15 /$ group). Separate groups of mice were used for each treatment group. DOI is classified as a phenalkylamine hallucinogen whose affinity for $5-\mathrm{HT}_{2 \mathrm{~A} / \mathrm{C}}$ receptors is strongly correlated to its hallucinogenic potency (Glennon et al., 1984; Titeler et al., 1988). DOI was dissolved in 0.9\% saline and injected intraperitoneally at $0.01 \mathrm{ml} / \mathrm{g}$ body weight. This dose of DOI has been shown to elicit a robust frequency of head twitch responses in mice (Darmani et al., 1990). Mice were videotaped for $20 \mathrm{~min}$ and scoring began immediately after injection. The head twitch response is a very distinctive paroxysmal head-twitching behavior that is easily distinguished from head bobbing, lateral movements of the head, or grooming. Scoring was also divided into four $5 \mathrm{~min}$ bins to evaluate any response pattern differences within the 20 min test. Ear scratch responses were also observed after DOI treatment. The results were similar to the head twitch responses in that mutant mice exhibited a greater response (data not shown).

\subsection{Data Analysis}

Data from the phosphoinositol hydrolysis and quantitative autoradiography experiments were analyzed by Student's t-test. Autoradiography data were analyzed independently within each brain region. Some slides were omitted from analyses due to experimental error (two wild-type samples). Membrane binding data from PFC were evaluated using non-linear regression analysis (SigmaPlot 8.0) that provided $\mathrm{B}_{\max }$ and $\mathrm{K}_{\mathrm{d}}$ values. The head twitch experiments were analyzed by ANOVA with genotype, drug dose, and sex as between subjects factors. Initial analyses indicated that the sexes did not differ in any measure; therefore male and female data were combined for subsequent analyses.

\section{RESULTS}

\subsection{Biochemical Characterization of naïve PKCy mutant and wild-type mice}

Phosphoinositol Hydrolysis-Figure 1 shows a comparison of 10 uM DOI-stimulated phosphoinositol hydrolysis in the prefrontal cortices of mutant and wild-type mice indicating that $5-\mathrm{HT}_{2 \mathrm{~A} / \mathrm{C}}$ function was significantly greater in mutant mice $\left(\mathrm{t}_{14}=2.58, \mathrm{p}<0.02\right)$. DOIstimulation over basal values averaged $125 \%$ in mutant PFC compared $108 \%$ in wild-type PFC.

[ ${ }^{125}$ I]-DOI Binding-Studies using membrane preparations from prefrontal cortex were performed to determine $\mathrm{B}_{\max }$ and $\mathrm{K}_{\mathrm{d}}$ values. Results from the non-linear regression analysis of saturation binding in the prefrontal cortex of mutant and wild-type mice demonstrated that the genotypes did not differ in receptor number $\left(\mathrm{B}_{\max }: 101.96 \mathrm{fmol} / \mathrm{mg}\right.$ protein \pm 0.91 and $111.60 \mathrm{fmol} / \mathrm{mg}$ protein \pm 9.70 ; mutant and wild-type respectively) or affinity $\left(\mathrm{K}_{\mathrm{d}}: 0.99 \mathrm{nM} \pm\right.$ 0.26 and $1.29 \mathrm{nM} \pm 0.31$; mutant and wild-type respectively). An analysis of the ratio of total binding over non-specific binding at each concentration indicated that the strongest signal to noise ratio (non-specific binding averaged $27.5 \%$ of total binding) was seen at $0.5 \mathrm{nM}$.

Therefore, this concentration was selected for the quantitative autoradiography experiments. 
$\left[{ }^{125}\right.$ I]-DOI Quantitative Autoradiography-Because the saturation binding experiments did not reveal differences in the number of binding sites or affinity for DOI in the prefrontal cortex, autoradiographic analyses of $\left[{ }^{125} \mathrm{I}\right]-\mathrm{DOI}$ binding sites in other brain regions associated with impulsivity and drug reward were done. The amount and distribution of binding sites were evaluated in 15 brain regions (Table 1). Levels of [ $\left.{ }^{125} \mathrm{I}\right]$-DOI binding were not different between mutant and wild-type mice in any brain region. Non-specific binding was low and was consistent across brain regions. Specific binding in the PFC $(33.09 \pm 1.55 \mathrm{fmol} / \mathrm{mg}$ and $31.12 \pm 1.13 \mathrm{fmol} / \mathrm{mg}$; mutant and wild-type respectively) was in the range seen in the saturation binding experiment at $0.5 \mathrm{nM}$ DOI $(32.81 \pm 1.65 \mathrm{fmol} / \mathrm{mg}$ and $25.42 \pm 2.91 \mathrm{fmol} /$ $\mathrm{mg}$; mutant and wild-type, respectively). However, differences in the amount of binding were observed among the brain regions with high levels found in prefrontal cortex, claustrum, lateral striatum, dorsal endopiriform nucleus, lateral olfactory tract, and olfactory tubercle. Lower levels of binding were seen in the striatal areas with rostral and caudal caudate putamen exhibiting the least. This is in agreement with previous studies that found similar patterns of receptor distributions in mouse (Li et al., 2003) and rat brain (McKenna et al., 1989a;Saavedra and Himeno, 1991). In the present study, $\left.{ }^{[25} \mathrm{I}\right]-\mathrm{DOI}$ binding was greater in rostral nucleus accumbens compared to caudal nucleus accumbens. This differs from what would have been predicted since Bowers et al. (2000) found that DOI-induced DA release was greater in caudal nucleus accumbens, suggesting an increased $5-\mathrm{HT}_{2 \mathrm{~A} / \mathrm{C}}$ receptor density in this region.

However, Appel et al. (1990) also found a gradient of decreasing receptor density from rostral to caudal regions.

\subsection{The effects of DOI on Behavioral responses}

Head Twitch Response-The DOI-induced head twitch response was included in this study to confirm the role of $5-\mathrm{HT}_{2 \mathrm{~A} / \mathrm{C}}$ receptors in regulating behavioral differences between PKC $\gamma$ mutant and wild-type mice. The results of an overall univariate ANOVA indicated significant main effects of genotype $\left(\mathrm{F}_{1,42}=9.20, \mathrm{p}<0.01\right)$ and drug treatment $\left(\mathrm{F}_{1,42}=94.71\right.$, $\mathrm{p}<0.0001)$, and a significant interaction between genotype and drug treatment $\left(\mathrm{F}_{1,42}=5.15\right.$, $\mathrm{p}<0.05$ ). These results are illustrated in Figure $2 \mathrm{~A}$ which shows that $2.5 \mathrm{mg} / \mathrm{kg}$ DOI significantly increased HTR in both genotypes compared to saline; however, mutant mice exhibited a greater number of DOI-induced HTR compared to wild-type mice. Saline injections had little effect on the head twitch response in either genotype, and were not different between genotypes.

When the patterns of head twitch responses in $2.5 \mathrm{mg} / \mathrm{kg}$ DOI-treated mutant and wild-type mice were analyzed in $5 \mathrm{~min}$ bins, a repeated measures ANOVA indicated a significant main effect of bins $\left(\mathrm{F}_{3,114}=13.8, \mathrm{p}<0.0001\right)$, genotype $\left(\mathrm{F}_{1,38}=32.3, \mathrm{p}<0.0001\right)$, and a significant bins $\mathrm{X}$ genotype interaction $\left(\mathrm{F}_{3,114}=6.9, \mathrm{p}<0.0001\right)$. Figure $2 \mathrm{~B}$ illustrates that the interaction is due to the different pattern of responses in mutant mice across the 20 min compared to wildtype mice; i.e., mutant mice demonstrate an increase in responses in the last $15 \mathrm{~min}$ of the test compared to wild-type mice.

\section{DISCUSSION}

The primary objective of the present study was to determine whether the neuronal-specific isotype of $\mathrm{PKC}, \mathrm{PKC} \gamma$, regulates $5-\mathrm{HT}_{2 \mathrm{~A} / \mathrm{C}}$ receptor number and function in the prefrontal cortex and whether there are behavioral correlates relating to this potential dysfunction. In support of this hypothesis the relevant findings of this study are: 1) in naive PKC $\gamma$ null mutant mice $5-\mathrm{HT}_{2 \mathrm{~A} / \mathrm{C}}$ receptor function, as measured by phosphoinositol hydrolysis, is increased in prefrontal cortex compared to wild-type mice; 2) receptor numbers are not different between the genotypes in PFC, or in several other brain regions; and 3) the head twitch response, a 
behavioral response to 5- $\mathrm{HT}_{2 \mathrm{~A}}$ receptor activation in the $\mathrm{PFC}$, is increased in $\mathrm{PKC} \gamma$ null mutant mice compared to wild-type littermate controls after an acute injection of $2.5 \mathrm{mg} / \mathrm{kg}$ DOI.

\subsection{Biochemical Assessments of $5-\mathrm{HT}_{2 \mathrm{~A} / \mathrm{C}}$ Receptors}

The results from the phosphoinositol hydrolysis experiment are indicative of an interaction of 5- $\mathrm{HT}_{2 \mathrm{~A} / \mathrm{C}}$ receptors with $\mathrm{PKC} \gamma$, such that $\mathrm{G}$ protein-coupling may be regulated by $\mathrm{PKC} \gamma$ after agonist stimulation. This interaction is part of a constitutive negative feed-back mechanism between PKC and G protein-coupling that maintains a homeostasis of receptor function (Berg et al., 2001; Kagaya et al., 1990). Roth et al. (1998) describes a potential pathway of desensitization involving PKC phosphorylation of the receptor itself. Upon agonist stimulation, $\mathrm{PKC}$ is activated via phospholipase $\mathrm{C}$-induced diacyl gylycerol and $\mathrm{Ca}^{2+}$ release. Activated $\mathrm{PKC}$ phophorylates the 5- $\mathrm{HT}_{2 \mathrm{~A} / \mathrm{C}}$ receptor which causes arrestins to bind to the receptor. Once arrestins are bound, receptor-G protein-coupling is compromised and the receptor loses function. We suggest that this negative feed-back desensitization process is dysregulated in PKC $\gamma$ null mutant mice such that phosphorylation of the receptor does not occur resulting in heightened receptor function. This indicates a specific role for the gamma isotype in the phosphorylation of the 5- $\mathrm{HT}_{2 \mathrm{~A} / \mathrm{C}}$ receptor. The effects of this dysregulation would be increased sensitivity to endogenous serotonin and to agonist stimulation resulting in alterations in serotonin-mediated behaviors. The apparent desensitization effects of DOI in the present experiment were observed under experimental conditions described in the Methods section; therefore, non-specific effects by DOI at $10 \mathrm{uM}$ or incomplete desensitization after a $60 \mathrm{~min}$ incubation period cannot be ruled out. However, Toscano et al. (1999) have shown that at 1 $\mathrm{uM}$ the potent $5-\mathrm{HT}_{2 \mathrm{~A} / \mathrm{C}}$ antagonists, mesulergine and methysergide, completely block $10 \mathrm{uM}$ DOI-stimulated phosphoinositol hydrolysis in rat spinal cord slices indicating that at $10 \mathrm{uM}$, DOI is specific for $5-\mathrm{HT}_{2 \mathrm{~A} / \mathrm{C}}$ receptors. In addition, maximum 5-HT-induced desensitization of 5- $\mathrm{HT}_{2 \mathrm{~A}}$ receptors occurs as early as $10 \mathrm{~min}$ and $5-\mathrm{HT}_{2 \mathrm{C}}$ receptors by $60 \mathrm{~min}$ in $\mathrm{CHO}$ cells (Berg et al. 2001). Therefore, in the present study the $60 \mathrm{~min}$ incubation time would be sufficient for desensitization.

It was important to measure whether the number of affinity of $5 \mathrm{HT}_{2 \mathrm{~A} / \mathrm{C}}$ receptors differed as a function of genotype to provide a detailed picture of how the deletion of $\mathrm{PKC} \gamma$ could affect the $5 \mathrm{HT}$ system. The results from membrane binding experiments using $\left[{ }^{125} \mathrm{I}\right]-\mathrm{DOI}$ and quantitative autoradiography of $\left[{ }^{125} \mathrm{I}\right]$-DOI binding sites in naïve mice indicated that mutant and wild-type mice do not differ in the number or affinity of 5- $\mathrm{HT}_{2 \mathrm{~A} / \mathrm{C}}$ receptors in prefrontal cortex, or in 14 other brain regions associated with impulsivity and drug reward. In vitro experiments have shown that the integrity of $5-\mathrm{HT}_{2 \mathrm{~A}}$ receptor mRNA is regulated by a PKCdependent mechanism (Ferry et al., 1994). However, the data from the present study suggest that $\mathrm{PKC} \gamma$ is not involved in this process and does not regulate receptor gene expression.

\subsection{Behavioral Assessments of $5 \mathrm{HT}_{2 \mathrm{~A} / \mathrm{c}}$ receptors}

In order to strengthen the argument that $5-\mathrm{HT}_{2 \mathrm{~A} / \mathrm{C}}$ receptor function in $\mathrm{PFC}$ is dysregulated in PKC $\gamma$ null mutant mice, mutant and wild-type mice were injected i.p. with DOI to produce HTR. Willins and Meltzer (1997) implicated the PFC as the primary brain region controlling 5-HT 2 -mediated HTR by directly administering DOI into the medial prefrontal cortex of rat. DOI injections produced head twitch responses in both genotypes; however, HTR was greater in mutant mice compared to wild-type controls. This suggests that $\mathrm{PKC} \gamma$ regulates this 5-

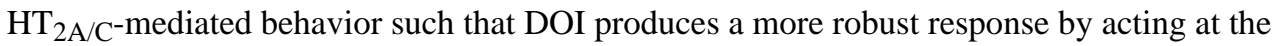
more functionally sensitive receptor found in mutant mice. The magnitude of the phosphoinositol hydrolysis difference between the genotypes did not completely correspond to the substantial difference in the head twitch response. Since the behavioral adaptations appear to be mediated by PKC $\gamma$, it is possible that other neurotransmitter systems that are regulated by $\mathrm{PKC} \gamma$ are involved in these responses. For example, we have shown previously 
that $\mathrm{PKC} \gamma$ regulates ethanol-stimulated $\mathrm{GABA}_{\mathrm{A}}$ receptor function in cortex (Harris et al., 1995). It has been shown that GABAergic drugs modulate head twitch behavior in rodents, perhaps through interaction with 5-HT 2 receptors (Handley and Singh, 1985; Moser and Redfern, 1988; Tadano et al., 2001). Feng et al (2001) reported that activation of 5-HT 2 receptors in the prefrontal cortex of rats increased in vitro PKC activity toward $\mathrm{GABA}_{\mathrm{A}}$ receptor $\gamma_{2}$ subunits. Moreover, the role of other neurotransmitter systems cannot be ruled out. Hayslett and Tizabi $(2003,2005)$ have shown that drugs acting at the nicotinic cholinergic and dopaminergic systems can regulate DOI-induced HTR.

The pattern of head twitch responses measured in 5 min bins suggests that acute desensitization does not occur in the mutant mice. In vitro studies have shown that 5- $\mathrm{HT}_{2 \mathrm{~A}}$ receptors are acutely desensitized, as measured by PI turnover, after as little as 15 min exposure to 5-HT (Kagaya et al., 1990; Van Oekelen et al., 2001).

\subsection{Relevance of current findings to impulsivity and ethanol consumption in PKCy mutants}

PKC $\gamma$ mutants show increased impulsivity in a signaled-nosepoke task (Bowers and Wehner, 2001). Impulsivity in humans and rodents has been associated with decreased serotonin levels in brain (Harrison et al., 1997; Leyton et al., 2001). However, Dalley et al. (2002) demonstrated that deficits in impulse control, using a simplified form of the 5 choice serial reaction task in rat, are positively associated with elevated levels of serotonin in the prefrontal cortex. This effect may be specifically associated with the $5-\mathrm{HT}_{2 \mathrm{~A}}$ receptor (Winstanely et al., 2004). In rodents, treatment with the 5- $\mathrm{HT}_{2 \mathrm{~A} / \mathrm{C}}$ agonist, DOI, increases impulsive responding (Evenden and Ryan, 1999; Evenden, 1998; Koskinen et al., 2000). If 5-HT $2 \mathrm{~A}$ receptor function is enhanced in PKC $\gamma$ mutant mice, the impulsive responding that we observed in these mice may be regulated by increased sensitivity to endogenous serotonin. This idea is more compelling in relationship to the findings of Dalley et al. (2002) because the appetitive signaled-nosepoke task that was used to evaluate impulsivity in the PKC mice is based on impulse control to an auditory stimulus (Bowers and Wehner, 2001). Thus, we speculate that alterations in $5 \mathrm{HT}_{2 \mathrm{~A} / \mathrm{C}}$ receptor function observed here may underlie the increased impulsivity phenotype in $\mathrm{PKC} \gamma$ mutants.

PKC $\gamma$ mutants also show increased consumption of ethanol (Bowers and Wehner, 2001). Although decreased density of $5-\mathrm{HT}_{2 \mathrm{~A}}$ receptors in the PFC have been associated with increased ethanol consumption (Blakley et al., 2001; Ciccocioppo et al., 1997; Ciccocioppo et al., 1999; McBride et al., 1993) a relationship between increased PI hydrolyis in this brain region and ethanol consumption has not been reported. However, using the selected rat lines, $\mathrm{P}$ and NP, Pandey et al. (1996) did show that in the high drinking P rats, 5- $\mathrm{HT}_{2 \mathrm{C}}-$-mediated PI hydrolysis and receptor binding are increased in choroid plexus. Therefore, in a general sense, $5-\mathrm{HT}_{2 \mathrm{~A} / \mathrm{C}}$ receptor function may be important in regulating a genetic vulnerability to ethanol consumption. With this in mind, the enhanced PI hydrolysis observed in the PFC of PKC $\gamma$ mutant mice supports the idea of a role for PKC $\gamma$ that includes ethanol drinking. Experiments to test the direct effects of $5-\mathrm{HT}_{2 \mathrm{~A} / \mathrm{C}}$ drugs on impulsivity and ethanol consumption in $\mathrm{PKC} \gamma$ mice are in progress. The results of these experiments will give a more definitive explanation for the role of $5-\mathrm{HT}_{2 \mathrm{~A} / \mathrm{C}}$ receptors in these behaviors.

In conclusion, these results suggest a role for PKC $\gamma$ in the functional regulation of the 5$\mathrm{HT}_{2 \mathrm{~A} / \mathrm{C}}$ receptor in the PFC as measured by PI hydrolysis. Therefore we speculate that a dysregulation of 5- $\mathrm{HT}_{2 \mathrm{~A} / \mathrm{C}}$ receptor function occurs in the $\mathrm{PFC}$ of $\mathrm{PKC} \gamma$ null mutant mice and that this may underlie the increased impulsivity, ethanol consumption (Bowers and Wehner, 2001), and DOI-induced head twitch (present study) demonstrated in these mice.

\section{Acknowledgements}

This work was supported by NIH grants, AA13901 to BJB; and AA03527 and AA13018 to JMW. 


\section{References}

Abeliovich A, Chen C, Goda Y, Silva AJ, Stevens CF, Tonegawa S. Modified hippocampal long-term potentiation in PKC $\gamma$-mutant mice. Cell 1993;75:1253-1262. [PubMed: 8269509]

Anji A, Hanley NRS, Kumari M, Hensler JG. The role of protein kinase C in the regulation of sertotonin-2A receptor expression. J Neurochem 2001;77:589-597. [PubMed: 11299321]

Appel NM, Mitchell WM, Garlick RK, Glennon RA, Teitler M, De Souza EB. Autoradiographic characterization of $( \pm)-1$-(2,5-dimethoxy-4- $\left[{ }^{125} \mathrm{I}\right]$ iodophenyl)-2-aminopropane ([ $\left.\left.{ }^{125} \mathrm{I}\right] \mathrm{DOI}\right)$ binding to 5-HT 2 and 5-HT 1 C receptors in rat brain. J Pharm Exp Ther 1990;255:843-857.

Backstrom JR, Miner LA, Sanders-Bush E, Sesack SR. Ultrastructural localization of the 5-HT $2 \mathrm{~A}$ receptor in the rat medial prefrontal cortex. Soc Neurosci Abs, P2001. Program Number, 380.19.

Barnes NM, Sharp T. A review of central 5-HT receptors and their function. Neuropharm 1999;38:10831152.

Berg KA, Stout BD, Maayani S, Clarke WP. Differences in rapid desensitization of 5hydroxytryptamine $2 \mathrm{~A}$ and 5-hydroxytryptamine $2 \mathrm{C}$ receptor-mediated phospholipase $\mathrm{C}$ activation. $\mathrm{J}$ Pharm Exp Ther 2001;299:593-602.

Berridge MJ, Downes Cp, Hanley MR. Lithium amplifies agonist-dependent phosphatidylinositol responses in brain and salivary glands. Biochem J 1982;206:587-595. [PubMed: 7150264]

Blakley GG, Pohorecky LA, Benjamin D. Bidirectional changes in ethanol consumption in rats with sitespecific antisense down-regulation of 5-hydroxytryptamine $2 \mathrm{~A}$ receptors in brain. J Pharm Exp Ther 2001;299:277-289.

Bowers BJ, Owen EH, Collins AC, Abeliovich A, Tonegawa S, Wehner JM. Decreased ethanol sensitivity and tolerance development in $\gamma$-protein kinase $\mathrm{C}$ null mutant mice is dependent on genetic background. Alcohol Clin Exp Res 1999;23:387-397. [PubMed: 10195808]

Bowers BJ, Henry MB, Thielen RJ, McBride WJ. Serotonin 5- $\mathrm{HT}_{2}$ receptor stimulation of dopamine release in the posterior but not anterior nucleus accumbens of the rat. J Neurochem 2000;75:16251633. [PubMed: 10987844]

Bowers BJ, Wehner JM. Ethanol consumption and behavioral impulsivity are increased in protein kinase C $\gamma$ null mutant mice. J Neurosci 2001;21:RC180. [PubMed: 11606660]

Bradford MM. A rapid and sensitive method for quantitation of microgram quantities of protein utilizing the principle of protein dye binding. Anal Biochem 1976;72:248-254. [PubMed: 942051]

Ciccocioppo R, Angeletti S, Colomba G, Gessa GL, Massi M. Autoradiographic analysis of 5- $\mathrm{HT}_{2 \mathrm{~A}}$ binding sites in the brain of Sardinian alcohol-preferring and nonpreferring rats. Eur J Pharm 1999;373:13-19.

Ciccocioppo R, Ge J, Barnes NM, Cooper SJ. Autoradiographic mapping of 5-HT2A binding sites in $\mathrm{P}$ and AA alcohol-preferring rats. Brain Res Bull 1997;44:33-37. [PubMed: 9288829]

Dalley JW, Cardinal RN, Robbins TW. Prefrontal executive and cognitive functions in rodents: neural and neurochemical substrates. Neurosci Biobehav Rev 2004;28:771-784. [PubMed: 15555683]

Darmani NA, Gerdes CF. Temporal differential adaptation of head-twitch and ear-scratch responses following administration of challenge doses of DOI. Pharm Biochem Behav 1995;50:545-550.

Darmani NA, Martin BR, Glennon RA. Withdrawal from chronic treatment with $( \pm)$-DOI causes supersensitivity to $5-\mathrm{HT}_{2}$ receptor-induced head-twitch behavior in mice. Eur. J. Pharm 1990;186:115-118.

Darmani NA, Martin BR, Glennon RA. Behavioral evidence for differential adaptation of the serotonergic system after acute and chronic treatment with ( \pm )-1-(2,5-dimethoxy-4-iodophenyl)-2-aminopropane (DOI) or ketanserin. J Pharm Exp Ther 1992;262:692-698.

Evenden JL, Ryan CN. The pharmacology of impulsive behavior in rats VI: the effects of ethanol and selective serotonergic drugs on response choice with varying delays of reinforcement. Psychopharm 1999; 146:413-421.

Evenden JL. The pharmacology of impulsive behavior in rats IV: the effects of selective serotonergic agents on a paced fixed consecutive number schedule. Psychopharm 1998;140:319-330.

Feng J, Cai X, Zhao J, Yan Z. Serotonin receptors modulate $\mathrm{GABA}_{\mathrm{A}}$ receptor channels through activation of anchored protein kinase C in prefrontal cortical neurons. J Neurosci 2001;21:6502-6511.

[PubMed: 11517239] 
Ferry RC, Unsworth CD, Artymyshyn RP, Molinoff PB. Regulation of mRNA encoding 5-HT $2 \mathrm{~A}$ receptors in $\mathrm{P} 11$ cells through a post-translational mechanism requiring activation of protein kinase C. J Biol Chem 1994;269:31850-31857. [PubMed: 7989358]

Fils-Aime M-L, Eckardt MJ, George DT, Brown GL, Mefford I, Linnoila M. Early-onset alcoholics have lower cerebrospinal fluid 5-hydroxyindoleacetic acid levels than late-onset alcoholics. Arch Gen Psychiatry Psychiatr 1996;53:211-216.

Franklin, KBJ.; Paxinos, G. The Mouse Brain in Stereotaxic Coordinates. Academic Press; 1997.

Glennon RA, Titeler M, McKenney JD. Evidence for 5-HT2 involvement in the mechanism of action of hallucinogenic agents. Life Sci 1984;35:2505-2011. [PubMed: 6513725]

Handley SL, Singh L. Modulation of 5-hydroxytryptamine-induced head-twitch response by drugs acting at GABA and related receptors. Br J Pharm 1985;86:297-303.

Harris RA, McQuilkin SJ, Paylor R, Abeliovich A, Tonegawa S, Wehner JM. Mutant mice lacking the $\gamma$ isoform of protein kinase $\mathrm{C}$ show decreased behavioral actions of ethanol and altered function of $\gamma$-aminobutyrate type A receptors. Proc Nat'l Acad Sci 1995;92:3658-3662.

Harrison AA, Everitt BJ, Robbins TW. Central 5-HT depletion enhances impulsive responding without affecting the accuracy of attentional performance: interactions with dopaminergic mechanisms. Psychopharm 1997;133:329-342.

Harrison AA, Everitt BJ, Robbins TW. Central serotonin depletion impairs both the acquisition and performance of a symmetrically reinforced go/no-go conditional visual discrimination. Behav Brain Res 1999;100:99-112. [PubMed: 10212057]

Hayslett RL, Tizabi Y. Effects of donepezil on DOI-induced head twitch response in mive: implications for Tourette syndrome. Pharm Biochem Behav 2003;76:409-415.

Hayslett RL, Tizabi Y. Effects of donepezil, nicotine and haloperidol on the central serotonergic system in mice: Implications for Tourette's syndrome. Pharm Biochem Behav 2005;81:879-886.

Ho M-Y, Al-Zahrani SSA, Al-Ruwaitea ASA, Bradshaw CM, Szabadi E. 5-hydroxytryptamine and impulse control: prospects for a behavioral analysis. J Psychopharm 1998;12:68-78.

Kagaya A, Mikuni M, Kusumi I, Yamamoto H, Takahashi K. Serotonin-induced acute desensitization of serotonin 2 receptors in human platelets via a mechanism involving protein kinase C. J Pharm Exp Ther 1990;255:305-311.

Knight AR, Misra A, Quirk K, Benwell K, Revell D, Kennett G, Bickerdike M. Pharmacological characterization of the agonist radioligand binding site of $5-\mathrm{HT}_{2} \mathrm{~A}, 5-\mathrm{HT}_{2 \mathrm{~B}}$ and $5-\mathrm{HT}_{2} \mathrm{C}$ receptors. Naunyn-Schmied Arch Pharmacol 2004;370:114-123.

Koskinen T, Ruotsalainen S, Puumala T, Lappalainen R, Koivisto E, Männistö PT, Sirviö J. Activation of 5- $\mathrm{HT}_{2 \mathrm{~A}}$ receptors impairs response control of rats in a five-choice serial reaction time task. Neuropharm 2000;39:471-481.

LeMarquand D, Pihl RO, Benkelfat C. Serotonin and alcohol intake, abuse, and dependence: findings of animal studies. Biol Psychiatry 1994a;36:395-421. [PubMed: 7803601]

LeMarquand D, Pihl RO, Benkelfat C. Serotonin and alcohol intake, abuse, and dependence: clinical evidence. Biol Psychiatry 1994b;36:326-337. [PubMed: 7993959]

Leyton M, Okazawa H, Diksic M, Paris J, Rosa P, Mzengeza S, Young SN, Blier P, Benkelfat C. Brain regional $\alpha-\left[{ }^{11} \mathrm{C}\right]$ methyl-1-tryptophan trapping in impulsive subjects with borderline personality disorder. Am J Psychiatry 2001;158:775-782. [PubMed: 11329401]

Li Q, Wichems CH, Ma L, Van de Kar LD, Garcia F, Murphy DL. Brain region-specific alterations of 5-HT $2 \mathrm{~A}$ and 5- $\mathrm{HT}_{2 \mathrm{C}}$ receptors in serotonin transporter knockout mice. J Neurochem 2003;84:12561265. [PubMed: 12614326]

MacDonald SC, Shay BL, Sawchuck MA, Hochman S, Buck CR. 5-HT2 receptor stimulation changes protein kinase $\mathrm{C}$ expression in the neonatal rat spinal cord. Soc Neurosci Abs. 2001Program Number 718.6.

McBride WJ, Bodart B, Lumeng L, Li T-K. Association between low contents of dopamine and serotonin in the nucleus accumbens and high alcohol preference. Alcohol Clin Exp Res 1995;19:1420-1422. [PubMed: 8749804]

McBride WJ, Chernet E, Rabold JA, Lumeng L, Li T-KK. Serotonin-2 receptors in the CNS of alcoholpreferring and -nonpreferring rats. Pharm Biochem Behav 1993;46:631-636. 
McKenna DJ, Nazarali AJ, Himeno A, Saavedra JM. Chronic treatment with ( \pm ) DOI, a psychotomimetic 5-HT 2 agonist, downregulates 5-HT 2 receptors in rat brain. Neuropsychopharm 1989a;2:81-87.

McKenna DJ, Nazarali AJ, Hoffman AJ, Nichols DE, Mathis CA, Saavedra JM. Common receptors for hallucinogens in rat brain: a comparative autoradiographic study using $\left[{ }^{125} \mathrm{I}\right] \mathrm{LSD}$ and $\left[{ }^{125} \mathrm{I}\right] \mathrm{DOI}$, a new psychotomimetic radioligand. Brain Res 1989b;476:45-56. [PubMed: 2536576]

Moser PC, Redfern PH. The effect of benzodiazepines on the 5-HT agonist-induced head-twitch response in mice. Eur J Pharm 1988;7:223-231.

Murphy JM, McBride WJ, Lumeng L, Li T-K. Regional brain levels of monoamines in alcohol- preferring and -nonpreferring lines of rats. Pharm Biochem Behav 1982;16:145-149.

Naik MU, Benedikz E, Hernandez I, Libien J, Hrabe J, Valsamis M, Dow-Edwards D, Osman M, Sacktor TC. Distribution of protein kinase $\mathrm{M} \zeta$ and the complete protein kinase $\mathrm{C}$ isoform family in rat brain. J Compar Neurol 2000;426:243-258.

Pandey SC, Lumeng L, Li T-K. Serotonin 2 C receptors and serotonin $2 \mathrm{C}$ receptor-mediated phosphoinositide hydrolysis in the brain of alcohol-preferring and alcohol-nonpreferring rats. Alcohol Clin Exp Res 1996;20:1038-1042. [PubMed: 8892525]

Pazos A, Cortés R, Palacios JM. Quantitative autoradiographic mapping of serotonin receptors in the rat brain. II. Serotonin-2 receptors. Brain Res 1985;346:231-249. [PubMed: 4052777]

Roth BL, Berry SA, Kroeze WK, Willins DL, Kristiansen K. Serotonin 5-HT 2 A receptors: molecular biology and mechanisms of regulation. Crit Reviews in Neurobiol 1998;12:319-338.

Saavedra, JM.; Himeno, A. Autoradiographic studies of 5-HT2 receptors. In: Schwarcz, R., editor. Kynurenine and Serotonin Pathways. New York: Plenum Press; 1991. p. 107-113.

Thomas KL, Everitt BJ. Limbic-cortical-ventral striatal activation during retrieval of a discrete cocaineassociated stimulus: a cellular imaging study with $\gamma$ protein kinase C expression. J Neurosci 2001;21:2526-2535. [PubMed: 11264326]

Titeler M, Lyon RA, Glennon RA. Radioligand binding evidence implicates the brain 5-HT2 receptor as a site of action for LSD and phenylisopropylamine hallucinogens. Psychopharm 1988;94:213-216.

Tadano T, Hozumi M, Satoh N, Oka R, Hishinuma T, Mizugaki M, Arai Y, Yasuhara H, Kinemuchi H, Niijima F, Nakagawasai O, Tan-no K, Kisara K. Central serotonergic mechanisms on head twitch responses induced by benzodiazepine receptor agonists. Int J Exp Clin Pharm 2001;62:157-162.

Toscano E, Romero G, Oset C, Del Río J. Pharmacological characteristics and regulation of 5-HT receptor-stimulated phosphoinositide hydrolysis in the rat spinal cord. Gen Pharm 1999;32:351-358.

Van Oekelen D, Jurzak M, Van de Wiel D, Van Hecke G, Luyten WHML, Leysen JE. Different regulation of rat 5- $\mathrm{HT}_{2 \mathrm{~A}}$ and rat 5- $\mathrm{HT}_{2 \mathrm{C}}$ receptors in $\mathrm{NIH} 3 \mathrm{~T} 3$ cells upon exposure to 5-HT and pipamperone. Eur J Pharm 2001;425:21-32.

Willins DL, Meltzer HY. Direct injection of 5- $\mathrm{HT}_{2 \mathrm{~A}}$ receptor agonists into the medial prefrontal cortex produces a head-twitch response in rats. J Pharm Exp Ther 1997;282:699-706.

Winstanely CA, Dalley JW, Theobald DEH, Robbins TW. Fractionating impulsivity: contrasting effects of central 5-HT depletion on different measures of impulsive behavior. Neuropsychopharm 2004;29:1331-1343. 


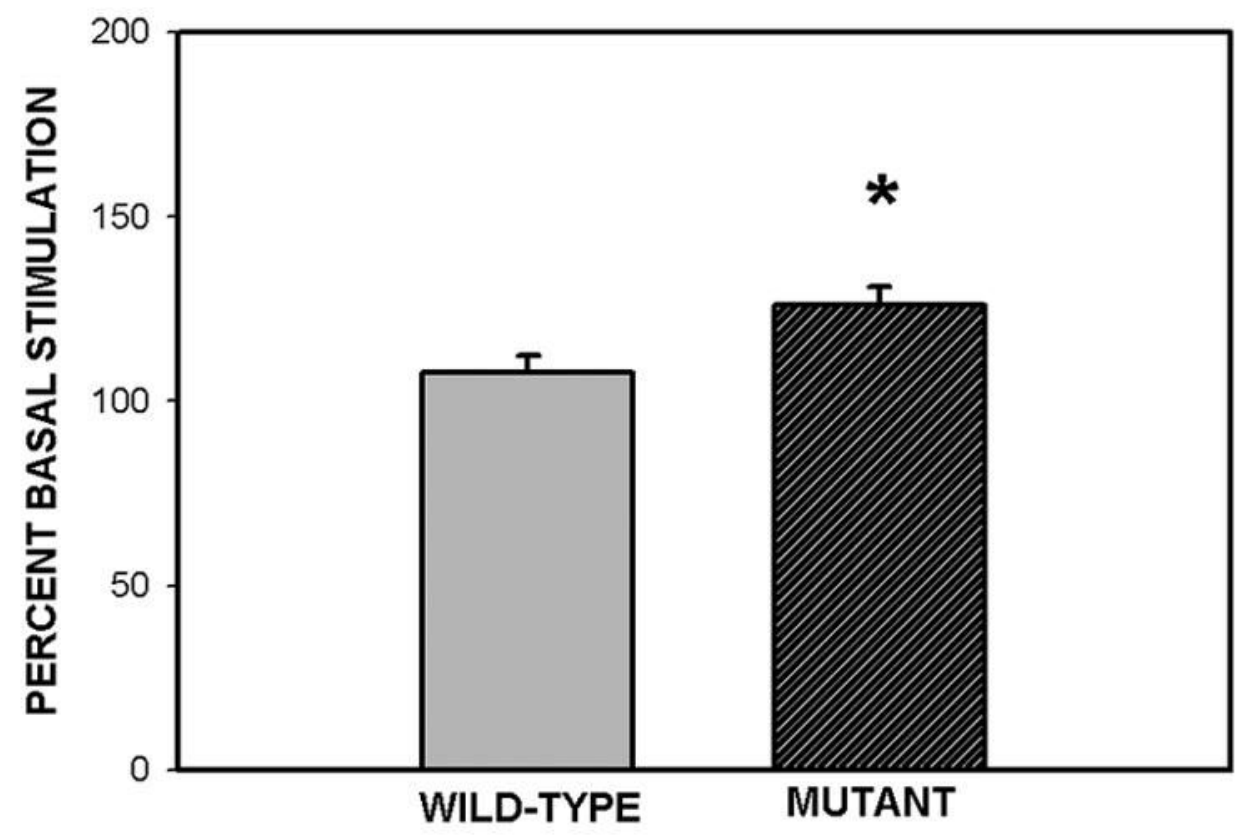

FIGURE 1.

DOI-stimulated phosphoinositol hydrolysis in PFC from mutant and wild-type mice. The percent of basal stimulation in mutant and wild-type mice in the presence of $10 \mathrm{uM} \mathrm{DOI}$ is greater in mutant mice compared to wild-type mice $(* \mathrm{p}<0.02)$. 

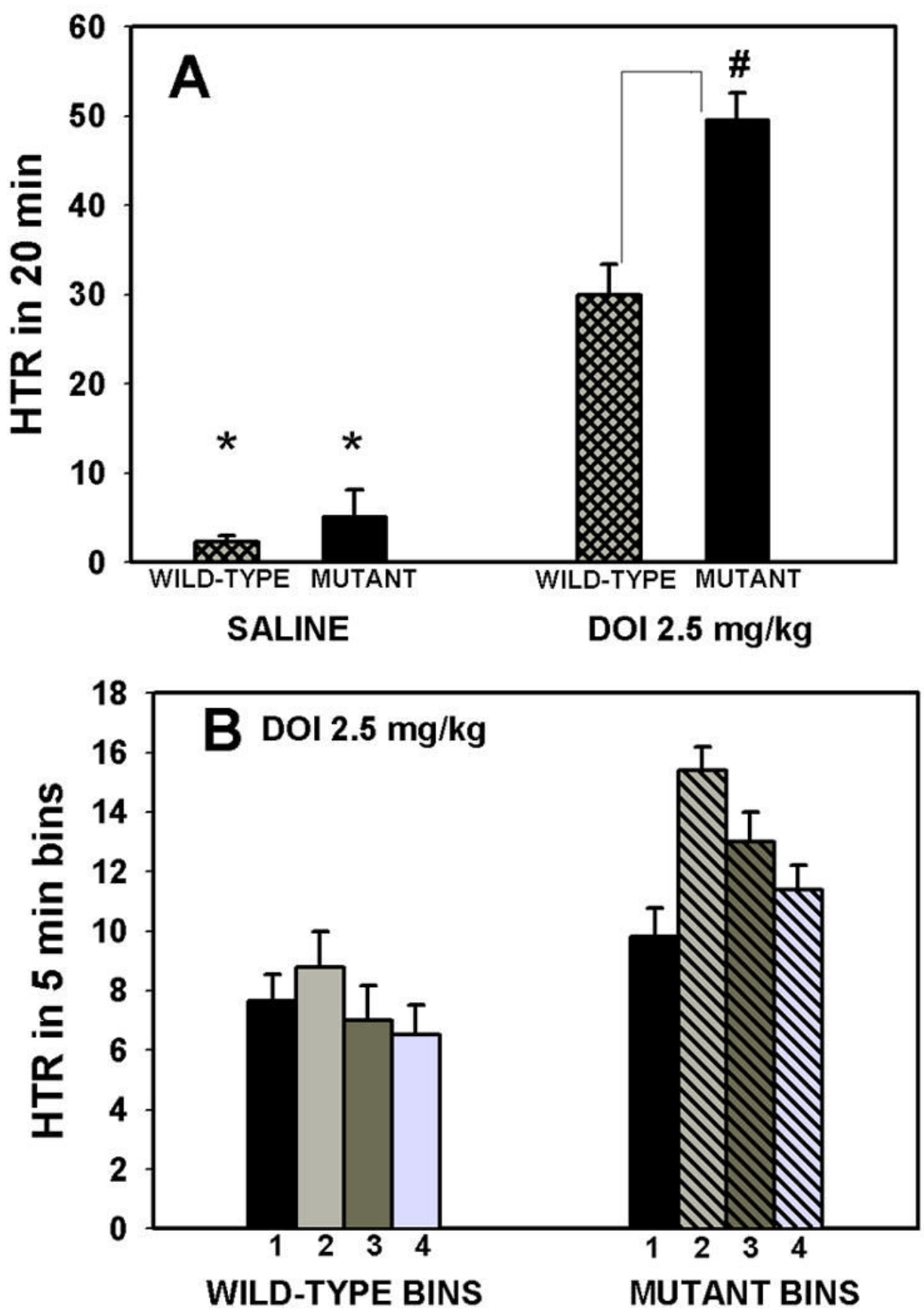

FIGURE 2.

Head twitch responses (HTR) in mutant and wild-type mice after acute doses of saline or 2.5 $\mathrm{mg} / \mathrm{kg}$ DOI. A. At $2.5 \mathrm{mg} / \mathrm{kg}$ DOI both mutant and wild-type mice had significantly greater responses than saline controls $(* \mathrm{p}<0.0001)$. Mutant mice exhibited significantly greater DOIinduced HTR that wild-type mice (\# $\mathrm{p}<0.01)$. B. Patterns of HTR in mutant and wild-type mice in four $5 \mathrm{~min}$ bins on Day 0 after an acute injection of $2.5 \mathrm{mg} / \mathrm{kg}$ DOI. Response patterns differed between genotypes $(\mathrm{p}<0.0001)$ which interacted with bins $(\mathrm{p}<0.0001)$. 
TABLE 1

Comparison of regional densities of $\left[{ }^{125} \mathrm{I}\right]$ DOI binding sites in PKC $\gamma$ mutant and wild-type mice

\begin{tabular}{|c|c|c|}
\hline \multirow[t]{2}{*}{ Region } & \multicolumn{2}{|c|}{ Specific Binding } \\
\hline & Mutant & Wild-type \\
\hline & \multicolumn{2}{|c|}{$\mathrm{f} \mathrm{mol} / \mathrm{mg}$ tissue equivalent $\pm S E$} \\
\hline Prefrontal cortex ${ }^{*}$ & $33.09 \pm 1.55$ & $31.17 \pm 1.13$ \\
\hline Lateral olfactory tract & $32.51 \pm 2.06$ & $26.70 \pm 2.93$ \\
\hline \multicolumn{3}{|l|}{ Cortex (rostral only) } \\
\hline anterior cingulate & $12.93 \pm 1.15$ & $14.69 \pm 1.21$ \\
\hline layer V & $20.03 \pm 0.79$ & $20.18 \pm 2.48$ \\
\hline Claustrum & $26.19 \pm 1.26$ & $26.05 \pm 2.76$ \\
\hline Dorsal endopiriform nucleus & $24.11 \pm 1.21$ & $25.52 \pm 2.90$ \\
\hline Lateral striatum & $27.99 \pm 1.56$ & $27.16 \pm 3.11$ \\
\hline Olfactory tubercle & $25.44 \pm 1.44$ & $25.84 \pm 2.25$ \\
\hline Septum & $9.59 \pm 1.43$ & $9.88 \pm 2.42$ \\
\hline Caudate putamen (rostral) & $8.65 \pm 0.86$ & $8.46 \pm 1.16$ \\
\hline Caudate putamen (caudal) & $4.73 \pm 0.33$ & $4.18 \pm 0.58$ \\
\hline \multicolumn{3}{|l|}{ Nucleus accumbens (rostral) } \\
\hline shell & $17.25 \pm 1.06$ & $17.24 \pm 2.06$ \\
\hline core & $14.88 \pm 0.98$ & $15.39 \pm 2.12$ \\
\hline \multicolumn{3}{|l|}{ Nucleus accumbens (caudal) } \\
\hline shell & $13.68 \pm 0.46$ & $12.39 \pm 1.36$ \\
\hline core & $9.58 \pm 0.42$ & $9.18 \pm 1.25$ \\
\hline
\end{tabular}

* Prefrontal cortex densities include FrA, PrL, MO, LO, DLO, VO as published in Franklin KBJ, Paxinos G (1997)

${ }^{\ddagger}$ Septum densities include DP, LSI, SHi, LSD as published in Franklin KBJ, Paxinos (1997)

Abbreviations: FrA, frontal association cortex; PrL, prelimbic cortex; MO, medial orbital cortex; LO, lateral orbital cortex; DLO, dorsolateral orbital cortex; VO, ventral orbital cortex; DP, dorsal pendicular nucleus; LSI, lateral septal nucleus, intermediate, SHi, septohippocampal nucleus; LSD, lateral septal nucleus, dorsal. 